\title{
Antibacterial Activity of Actinobacteria Isolated from Mangroves of Andaman and Nicobar Islands, India
}

\section{Sumitha Gopalakrishnan ${ }^{1}$, Jai Sunder ${ }^{1 *}$, Venu Sasidharan ${ }^{2}$, Sai Elangovan Subramanian ${ }^{2}$}

\author{
${ }^{1}$ ICAR-Central Island Agricultural Research Institute, Garacharma, Andaman Eo Nicobar Islands, India; ${ }^{2}$ Pondi- \\ cherry Central University, Brookshabad, Andaman E̋ Nicobar Islands, India.
}

\begin{abstract}
Mangrove environment supports a rich and diverse group of microorganisms. These bacteria perform various ecologically important activities in these ecosystems like nitrogen fixation, methanogenesis etc. and also by the release of various kinds of compounds in the environment. In the present study, sediment samples from the three zones of mangrove ecosystems viz. proximal, middle and distal were examined for Actinobacteria. A total of 23 Actinobacterial colonies were isolated. The THBC varied between $24 \pm 0.82 \times 10^{6}$ in Proximal Zone to $50 \pm 1.7 \times 10^{6}$ in the distal zone in Burmanallah with an increasing trend in the THBC from proximal to the distal zone. While in Carbyn's Cove, THBC ranged between $20 \pm 2.16 \times 10^{6}$ in the middle zone and $42 \pm 1.7 \times 10^{6}$ in the distal zone. An increase in the TAC towards sea was obtained in TAC from Nil in the distal zone to $4 \pm 1.7 \times 10^{6}$ in the proximal zone in Burmanallah and in Carbyn's Cove, TAC ranged between $0.0006 \pm 0.0001 \mathrm{X} 10^{6}$ in the distal zone and $8 \pm 0.47 \mathrm{X} 10^{6}$ in the proximal zone. ANOSIM (R: 0.932 ) have shown that microbial community structure was not different between sites and zones at a significance level of $1.7 \%$. This also confirmed the similarity seen in the MDS. The diversity is high in the proximal stations and in the distal zone of Carbyn's Cove. The Actinobacteria viz. Micromonospora sp., Streptomyces aburaviensis, Streptomyces aurantiogriesius, Streptomyces aurofasciculus, Streptomyces flavoviridis and Nocardia astreoides. S. aurantiogriesius have shown the maximum activity with more than $10 \mathrm{~mm}$ zone of inhibition against Klebseilla sp., E. coli, $V$. cholera and $S$. flexheri. While $S$. aburaviensis have shown high activity against Klebseilla sp., E. coli and $V$. cholera. The other Streptomyces species like $S$. aurofasciculus and $S$. flavoviridis have shown medium activity against the pathogens. The present study could be drawn that marine environment yields a greater number of isolates per source that is comparable with that obtained from mangrove soils. On the other side, the number of isolates obtained from mangrove sediments is lower, particularly in the case of Actinobacteria. The present study also shows that the two study area Barmanallha and Carbyn's Cove) of south Andaman have high potential Actinobacteria with bioactivity useful for identification of some novel compounds in future.
\end{abstract}

Keywords | Mangrove, South Andaman, Bioactivity, Micromonospora, Streptomyces, Nocardia

Editor | Kuldeep Dhama, Indian Veterinary Research Institute, Uttar Pradesh, India.

Received | November 30, 2015; Accepted | May 11, 2016; Published | May 19, 2016

*Correspondence | Jai Sunder, ICAR- Central Island Agricultural Research Institute, Garacharma, Andaman \& Nicobar Islands, India; Email: jaisunder@ rediffmail.com

Citation | Gopalakrishnan S, Sunder J, Sasidharan V, Subramanian SE (2016). Antibacterial activity of actinobacteria isolated from mangroves of Andaman and Nicobar Islands, India. Adv. Anim. Vet. Sci. 4(5): 230-236.

DOI | http://dx.doi.org/10.14737/journal.aavs/2016/4.5.230.236

ISSN (Online) | 2307-8316; ISSN (Print) | 2309-3331

Copyright $(2016$ Gopalakrishnan et al. This is an open access article distributed under the Creative Commons Attribution License, which permits unrestricted use, distribution, and reproduction in any medium, provided the original work is properly cited.

\section{INTRODUCTION}

$\mathrm{M}$ angroves are coastal wetland forests mainly found at the intertidal zone of estuaries, back waters, deltas, creeks, lagoons and mudflats of tropical latitudes. According to the latest estimate by the Forest Survey of India (FSI, 2013), the total mangrove area is approximately $4,628 \mathrm{~km}^{2}$ in India, out of which, $604 \mathrm{~km}^{2}$ occurs in An- daman and Nicobar Islands (Damroy and Krishnan, 2005; Ragavan et al., 2015). Fertility of the mangrove sediment results from the microbial decomposition of organic matter and recycling of nutrients (Sahoo, 2009). The activities of bacteria include nitrogen fixation, methanogenesis, and production of antibiotics, enzymes and human pathogens. The mangrove environment is a potent source for the isolation of antibiotic producing Actinobacteria, the 
Gram positive bacteria with branched filaments. Among the microorganisms Actinobacteria gained special importance due to their capacity to produce bioactive secondary metabolites (Thenmozhi et al., 2012) and more recently Himalomycin A antibiotic was isolated from Actinomycetes (Flora et al., 2015). On the whole, the last 55 years have seen the discovery of more than 12,000 antibiotics, and Most of the bioactive compounds from actinobacteria sort into several major structural classes such as amino glycosides (e.g. streptomycin and kanamycin), ansamycins (e.g. rifampin), anthracyclines (e.g. doxorubicin), $\beta$-lactam (cephalo-sporins), macrolides (e.g. erythromycin) and tetracycline (Basavaraj et al., 2010). According to Gunasekaran and Thangavel (2013), the Bay of Bengal harbour rich source of biologically active actinobacteria which has the capacity to produce novel and effective secondary metabolites with antimicrobial functions.

The mangrove ecosystems are generally divided into three zones according to the proximity to the coast viz. Proximal (near to coast), Middle and Distal (near to terrestrial environment). It is a confirmed fact that these zones does differ each other in mangrove species composition, faunal diversity and other physico-chemical factors. In this study, the Actinobacteria from the sediments of two mangrove environments (Burmanallah and Carbyn's Cove) of South Andaman region was carried out for their diversity and antibacterial activity of the Actinobacteria extract against six pathogens.

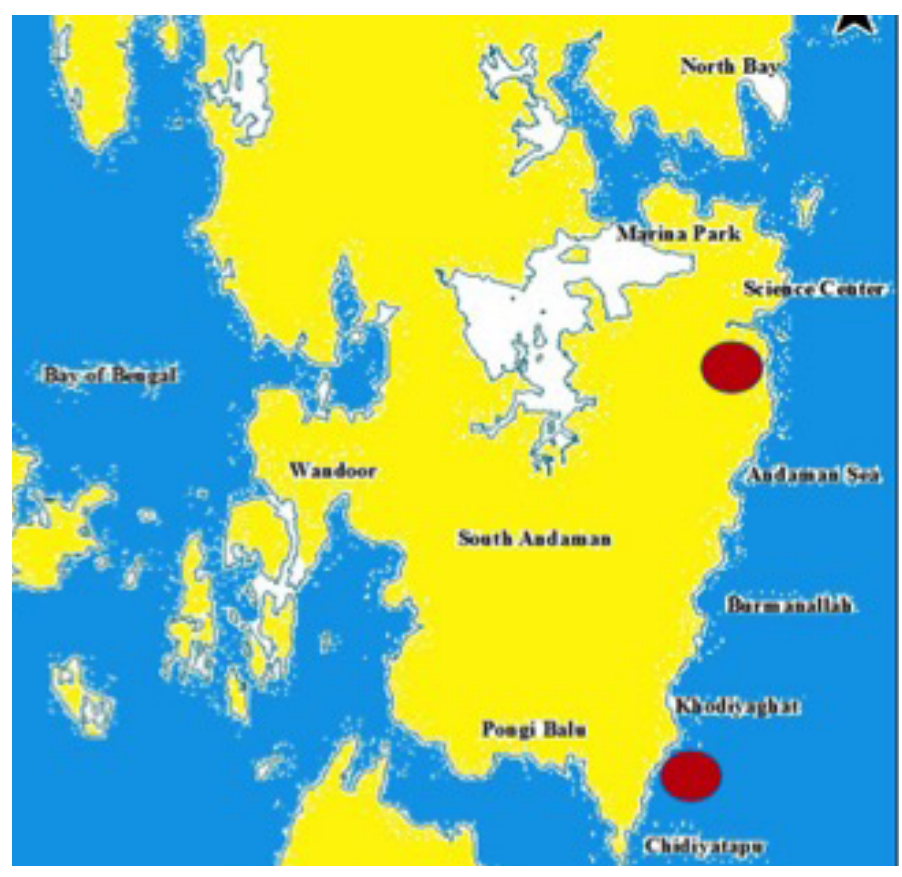

Figure 1: South Andaman map showing study area

\section{MATERIALS AND METHODS}

The sediment samples were collected aseptically from Proximal (near to coast), Middle and Distal (near to terrestrial environment) zones of mangrove ecosystems in Burmanallah and Carbyn's Cove (Figure 1). Samples were air dried for 4 days at room temperature and $1 \mathrm{gm}$ of dried sample was serially diluted in $50 \%$ of $9 \mathrm{ml}$ sterile seawater up to $10^{-6}$ dilution. From the dilution, $1 \mathrm{ml}$ was inoculated into antibiotic incorporated Amphotericin $(10 \mu \mathrm{L})$ and Nystatin $(50 \mu \mathrm{L})$ starch casein agar medium by pour plate method and incubated at $28^{\circ} \mathrm{C}$ for 7 to 9 days (Sahoo, 2009; Sivakumar et al., 2005). After the incubation, the appeared colonies were counted by using colony counter.

Morphologically different Actinobacteria were selected, identified to the species level based on the microscopic and biochemical test results (Sivakumar et al., 2005; Nonomura, 1974). Morphological observation of colony characteristics such as amount and colour of vegetative growth and the presence and colour of aerial mycelium and spores, and again the presence of diffusible pigments were recorded for each isolate and studied colonial growth on agar plate (Labede et al., 1985). The colonies isolated were purified by streaking method and then incubated at $28^{\circ} \mathrm{C}$ for 6 days. The identification was done morphologically and biochemically (Tamura et al., 2011; Nonomura, 1974; Sherling and Gotileb 1966). The cultures were grown on ISP medium 2, ISP medium 3, ISP medium 4, ISP medium 5 and ISP medium 7 (Tyrosine Agar) as described by Sherling and Gotileb (1966) and El-Habib and Magda (2012) to examine the pigment production. The isolates were inoculated in Marine Actinobacteria growth (MAG) broth and incubated for 4-5 days and observed for aerial mycelium under 100x light microscope. Utilization of carbohydrates, salt tolerance 0 to $20 \%$ (w/v) $\mathrm{NaCl}$ and temperature tolerance along with urease activity, oxidase test, catalase test, protease, lipase, amylase, chitinase and cellulase activity were also tested (El-Habib and Magda, 2012; Gopalakrishnan et al., 2014).

The purified Actinobacterial strains obtained were tested for antibacterial activity against the human pathogens (Streptococcus sp., Klebsiella sp., Pseudomonas sp., E. coli, Vibrio cholera and Shigella flexnerii) by disc diffusion method (Badji et al., 2006; Alimuddin et al., 2011). Three Actinobacteria strains were selected based on their preliminary screening for antibacterial activity against the pathogens and were inoculated in MAG broth and incubated at room temperature for seven days. The culture broths were centrifuged at $8000 \mathrm{rpm}$ for 10 minutes, and supernatant were used to test antibacterial activity. The pathogens were inoculated into nutrient agar medium by spread plate method. Filter paper discs were dipped in the centrifuged culture broth and placed on the plates by using sterile forceps and incubated at room temperature for 24-48 hours. The diameter of the zones of complete inhibition was measured. The results were statistically analysed using Microsoft Excel and PRIMER v7 software. 


\section{RESULTS AND DISCUSSION}

The total heterotrophic bacterial count (THBC) varied between $24 \pm 0.82 \times 10^{6}$ in Proximal Zone to $50 \pm 1.7$ X $10^{6}$ in the distal zone in Burmanallah (Table 1) which have shown an increasing trend in the THBC from proximal to the distal zone. While in Carbyn's Cove, THBC ranged between $20 \pm 2.16 \times 10^{6}$ in the middle zone and $42 \pm 1.7$ $\mathrm{X} 10^{6}$ in the distal zone. The Total Actinobacterial Count (TAC) varied between Nil in the distal zone to $4 \pm 1.7$ $\mathrm{X} 10^{6}$ in the proximal zone. A similar result, an increase in the TAC towards sea was obtained in Carbyn's Cove, where the TAC ranged between $0.0006 \pm 0.0001 \times 10^{6}$ in the distal zone and $8 \pm 0.47 \times 10^{6}$ in the proximal zone.

Table 1: Total Heterotrophic Bacterial Count (THBC) and Total Actinobacterial Count (TAC) from three zones of mangroves

\begin{tabular}{|c|c|c|c|c|c|c|}
\hline \multirow[t]{3}{*}{ Station } & \multirow{2}{*}{\multicolumn{2}{|c|}{$\begin{array}{l}\text { Proximal } \\
\text { (cfu/ml) }\end{array}$}} & \multirow{2}{*}{\multicolumn{2}{|c|}{$\begin{array}{l}\text { Middle } \\
\text { (cfu/ml) }\end{array}$}} & \multirow{2}{*}{\multicolumn{2}{|c|}{$\begin{array}{l}\text { Distal } \\
\text { (cfu/ml) }\end{array}$}} \\
\hline & & & & & & \\
\hline & $\begin{array}{l}\text { THBC } \\
\left(\mathrm{x} 10^{6}\right)\end{array}$ & $\begin{array}{l}\text { TAC } \\
\left(\mathrm{x} 10^{6}\right)\end{array}$ & $\begin{array}{l}\text { THBC } \\
\left(\mathrm{x} 10^{6}\right)\end{array}$ & $\begin{array}{l}\text { TAC } \\
\left(\mathrm{x} 10^{6}\right)\end{array}$ & $\begin{array}{l}\text { THBC } \\
\left(\mathrm{x} 10^{6}\right)\end{array}$ & $\begin{array}{l}\text { TAC } \\
\left(\mathrm{x} 10^{6}\right)\end{array}$ \\
\hline $\begin{array}{l}\text { Burma- } \\
\text { nallah }\end{array}$ & $\begin{array}{l}35 \pm \\
2.16\end{array}$ & $\begin{array}{l}4 \pm \\
1.7\end{array}$ & $\begin{array}{l}20 \pm \\
2.16\end{array}$ & $\begin{array}{l}3 \pm \\
0.94\end{array}$ & $\begin{array}{l}42 \pm \\
1.7\end{array}$ & 0 \\
\hline $\begin{array}{l}\text { Carbyn's } \\
\text { Cove }\end{array}$ & $\begin{array}{l}24 \pm \\
0.82\end{array}$ & $\begin{array}{l}8 \pm \\
0.47\end{array}$ & $\begin{array}{l}36 \pm \\
0.47\end{array}$ & $\begin{array}{l}2 \pm \\
0.82\end{array}$ & $\begin{array}{l}50 \pm \\
1.7\end{array}$ & $\begin{array}{l}0.0006 \\
\pm 0.0001\end{array}$ \\
\hline
\end{tabular}

\section{IDENTIFICATION OF ACTINOBACTERIA}

23 colonies of actinobacteria were isolated from the sediment samples during the present study. Isolated Actinobacteria were identified as Micromonospora sp. (S1), Streptomyces aburaviensis (S2), Streptomyces aurantiogriesius (S3), Streptomyces aurofasciculus (S4), Streptomyces flavoviridis (S5), Nocardia astreoides (S6) Bifidobacteria spp. (S7), Arthrobacter spp. (S8) and Pseudonocardia spp. (S9).

Streptomyces spp. were the most prominent actinobacteria isolated from the mangrove environment during the pres- ent study (Table 2). The other genera represented by $\mathrm{Mi}$ cromonospora, Nocardia, Pseudonocardia, Bifidobacteria and Artbrobacter were few in number. Carbyn's Cove was found to harbour more number of actinobacterial species than Burmanallah. The proximal zone was found to be more diverse than the other zones in both the stations while no actinobacteria could be isolated from the distal zone of Burmanallah.

The Bray-curtis similarity group average analysis of zones have shown that Burmanallah distal Zone is completely different from other stations, Carbyn's Cove and Burmanallah Middle Zones have shown more similarity than other stations (Figure 2). Also the proximal zones have also shown similarity.

According to ANOSIM (R: 0.932), microbial community structure was not different between sites and zones at a significance level of $1.7 \%$ (Figure 3). This also confirmed the similarity seen in the MDS.

It is evident from the diversity indices that the diversity is high in the proximal stations and in the distal zone of Carbyn's Cove (Table 3). The evenness is more or less similar in all zones but dominance is high in distal and proximal zone of Carbyn's Cove.

Carbyn's Cove beach is one of the important tourist places in the Andaman Island with one side of the area covered by lush of mangroves and the other side rocky. The organic matter rich sediments by the way of influxes from land through the fresh water stream and by the way of high human interference in the proximal zone make it more productive. In Burmanallah, anthropogenic interventions were found to be much less than Carbyn's Cove. Actinobacteria were found to dominate in sediments where organic load is more (Udotong et al., 2008; Dastager and Damare, 2013). So the more isolates from Carbyn's cove can be attributed by more anthropogenic activities in this mangrove area.

Table 2: Occurrence of Actinobacteria in various zones along the mangroves

$\begin{array}{lllllll}\text { Actinobacteria } & \mathbf{C C P}(\mathbf{X ~ 1 0}) & \mathbf{B R P}(\mathbf{X ~ 1 0}) & \mathbf{C C M}(\mathbf{X ~ 1 0}) & \mathbf{B R M}\left(\mathbf{X ~ 1 0} \mathbf{1 0}^{6}\right) & \mathbf{C C D}\left(\mathbf{X ~ 1 0} \mathbf{1}^{2}\right) & \mathbf{B R D}(\mathbf{X ~ 1 0}) \\ \text { Micromonospora sp. } & 0 & 0 & 1 \pm 0.82 & 1 \pm 1.4 & 1 \pm 0.82 & 0 \\ \text { Streptomyces aburaviensis } & 1 & 0 & 0 & 0 & 1 & 0 \\ \text { Streptomyces aurantiogriesius } & 1 \pm 0.82 & 1 \pm 0.82 & 0 & 0 & 1 \pm 0.82 & 0 \\ \text { Streptomyces aurofasciculus } & 2 \pm 0.82 & 1 \pm 0.82 & 0 & 0 & 1 \pm 0.82 & 0 \\ \text { Streptomyces flavoviridis } & 1 & 0 & 1 \pm 0.82 & 1 \pm 0.82 & 1 & 0 \\ \text { Nocardia astreoides } & 1 \pm 0.82 & 0 & 0 & 0 & 0 & 0 \\ \text { Bifidobacteria spp. } & 1 \pm 0.82 & 1 \pm 0.47 & 0 & 0 & 0 & 0 \\ \text { Arthrobacter spp. } & 1 & 1 \pm 1.4 & 0 & 0 & 0 & 0 \\ \text { Pseudonocardia spp. } & 0 & & 0 & 1 \pm 1.4 & 1 \pm 1.4 & 0\end{array}$

*CCP: Carbyn's Cove Proximal zone; CCM: Carbyn's Cove Middle Zone; CCD; Carbyn's Cove Distal zone; BRP; Burmanallah Proximal Zone; BRM; Burmanallah Middle Zone; BRD; Burmanallah Distal Zone 


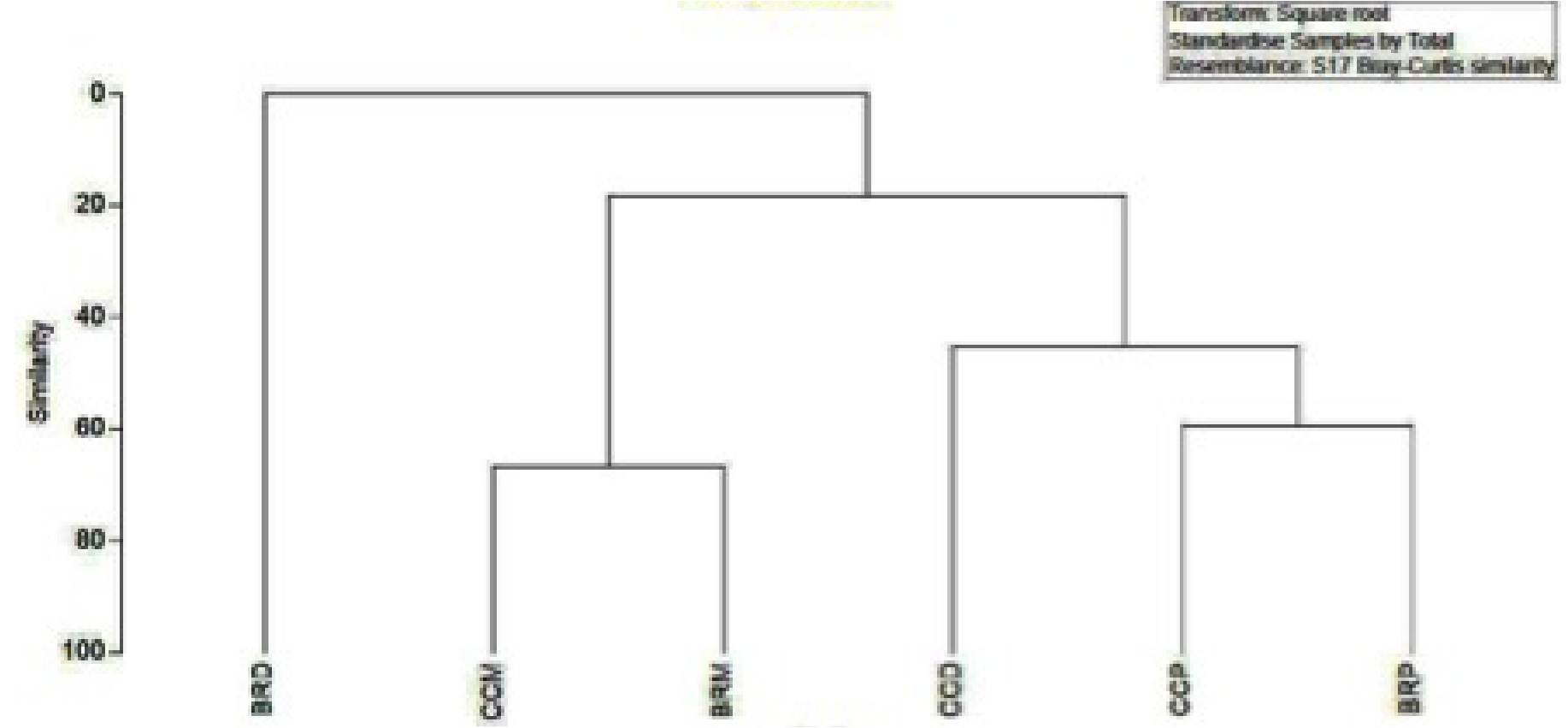

Figure 2: Similarity between the proximal, middle and the distal mangrove zones in Carbyn's Cove and group average

Table 3: Actinobacterial diversity in various zones in Carbyn's Cove and Burmanallah

$\begin{array}{llllllll}\text { STATION } & \mathbf{S} & \mathbf{d} & \mathbf{J} & \text { Brillouin } & \text { Fisher } & \text { H(log } \mathbf{2}) & \text { 1-Lambda } \\ \text { CCP } & 7 & 1.09956 & 0.9956 & 1.828 & 1.357 & 2.795 & 0.8581 \\ \text { BRP } & 4 & 0.6198 & 1 & 1.274 & 0.7864 & 2 & 0.756 \\ \text { CCM } & 2 & 0.2411 & 1 & 0.6015 & 0.3932 & 1 & 0.508 \\ \text { BRM } & 3 & 0.4393 & 1 & 1.012 & 0.5898 & 1.585 & 0.6738 \\ \text { CCD } & 6 & 2.791 & 1 & 1.097 & - & 2.585 & 1 \\ \text { BRD } & 0 & - & - & - & - & 0 & -\end{array}$

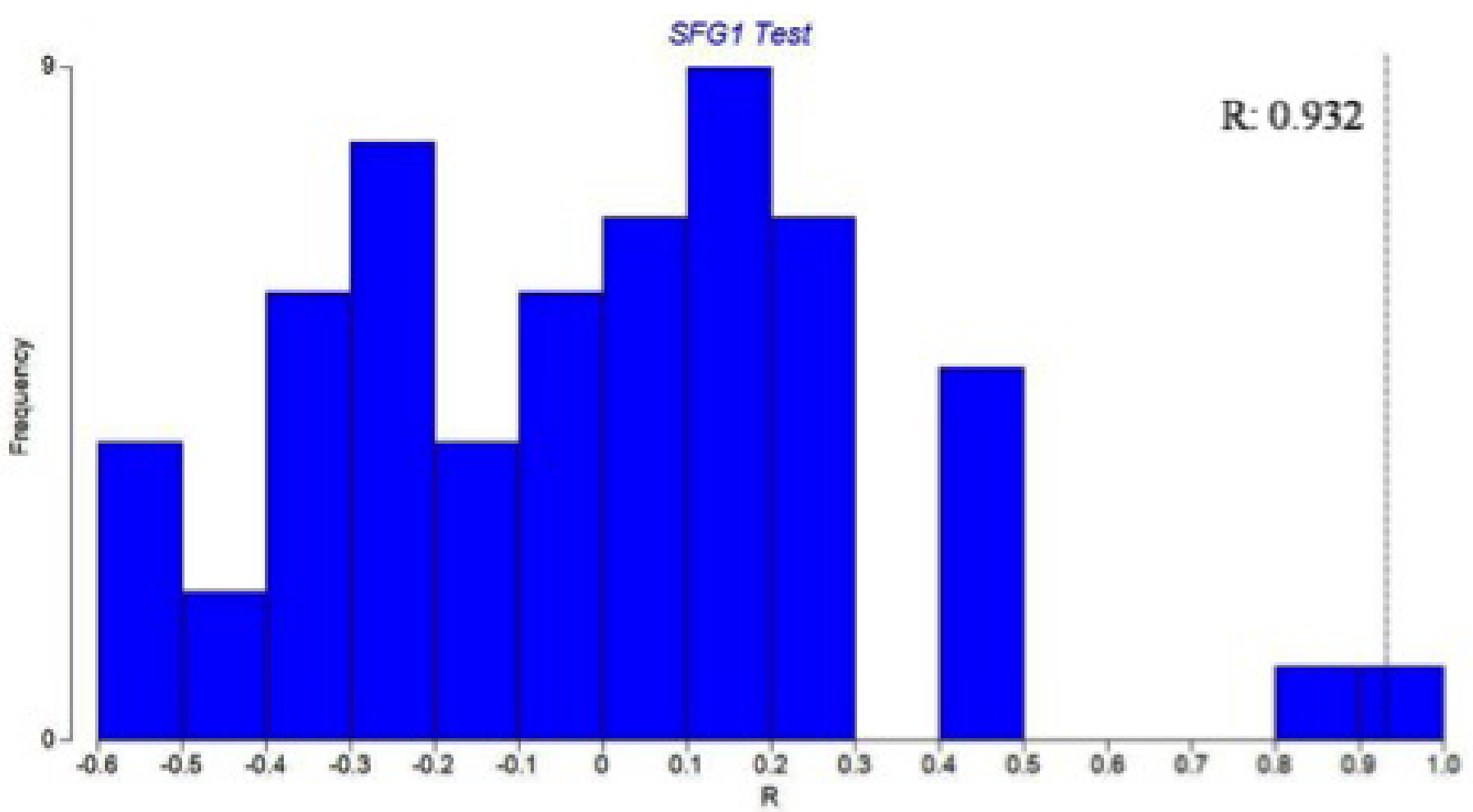

Figure 3: Microbial community structure in the mangrove zones: Permutation distribution of the test statistic $\mathrm{R}$ 
According to Gunasekaran and Thangavel (2013), the Bay of Bengal may harbor rich source of biologically active actinobacteria which has the capacity to produce novel and effective secondary metabolites with antimicrobial functions.

\section{Antimicrobial Activity}

New drugs, notably antibiotics, are urgently needed to arrest and reverse the relentless spread of antibiotic resistant pathogens causing life threatening infections and risk which are undermining the viability of health-care systems all around the world (Talbot et al., 2006). During the present study, six morphologically unlike isolates, which showed antibacterial activity against various human pathogens, were selected and identified as Micromonospora sp. (S1), Streptomyces aburaviensis (S2), Streptomyces aurantiogriesius (S3), Streptomyces aurofasciculus (S4), Streptomyces flavoviridis (S5) and Nocardia astreoides (S6). Among these strains, S. aburaviensis (S2), S. aurantiogriesius (S3), S. aurofasciculus (S4) and S. flavoviridis (S5) have shown good inhibition zone (Figure 4) against various human pathogens.

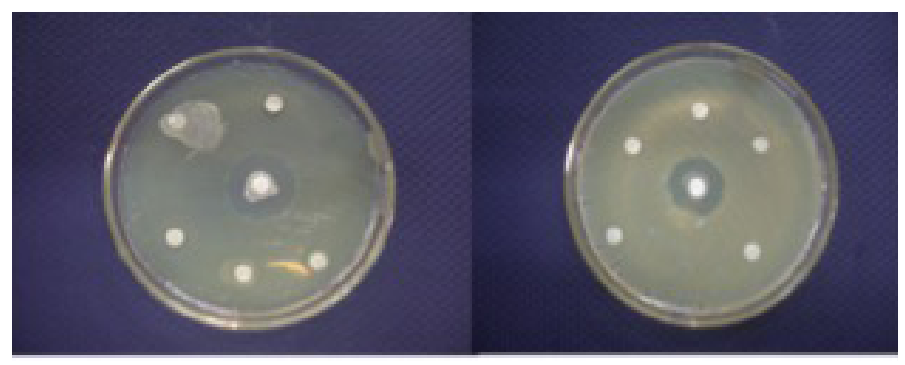

Figure 4: Antibacterial activity of Streptomyces sp. against pathogens

Filamentous bacteria belonging to the order Actinomy- cetales, especially Micromomospora and Streptomyces strains, have a unique and proven capacity to produce novel antibiotics (Bentley et al., 2002), hence, the continued interest in screening such organisms for new bioactive and it is also becoming increasingly clear that un and under-explored habitats, such as desert biomes and marine ecosystems, are a very rich source of novel actinobacteria which have the capacity to produce interesting new bioactive compounds, including antibiotics (Jeffrey et al., 2007; Hong et al., 2009). Micromonospora sp. inhibited the growth of Streptococcos sp. While Nocardia asteroides have shown antibacterial activity against Pseudomonas sp. only. While all Streptomycetes have shown high activity against all the pathogens tested. It could be seen that S. aurantiogriesius (S 4) have shown the maximum activity with more than $10 \mathrm{~mm}$ zone of inhibition against Klebseilla sp., E. coli, $V$. cholera and $S$. flexheri, where Ampicillin antibiotic disc has shown maximum of $10 \mathrm{~mm}$ clearing zone (Figure 5).

While $S$. aburaviensis (S3) have shown high activity against Klebseilla sp., E. coli and V. cholera, where Ampicillin disc is used as standard. The other Streptomyces species like $S$. aurofasciculus (S5) and S. flavoviridis (S6) have shown medium activity against the pathogens. The most important observation was that all Streptomyces species have shown higher activity against Klebseilla sp., E. coli and V. cholerae. Micromonospora sp. and S. aurofasciculus have shown the highest activity against Streptococcus sp. While S. aburaviensis and S. aurantiogriesius have shown highest activity against all other pathogens. In each experiment Gentamycin 10mg (Himedia) and Ampicillin 10mg antibiotic discs (Himedia) were used as standards. Gentamycin has shown clearing zone maximum $22 \mathrm{~mm}$ for E.coli and Klebsiella sp. But for Streptococci, it has shown $5 \mathrm{~mm}$ clearing zone.

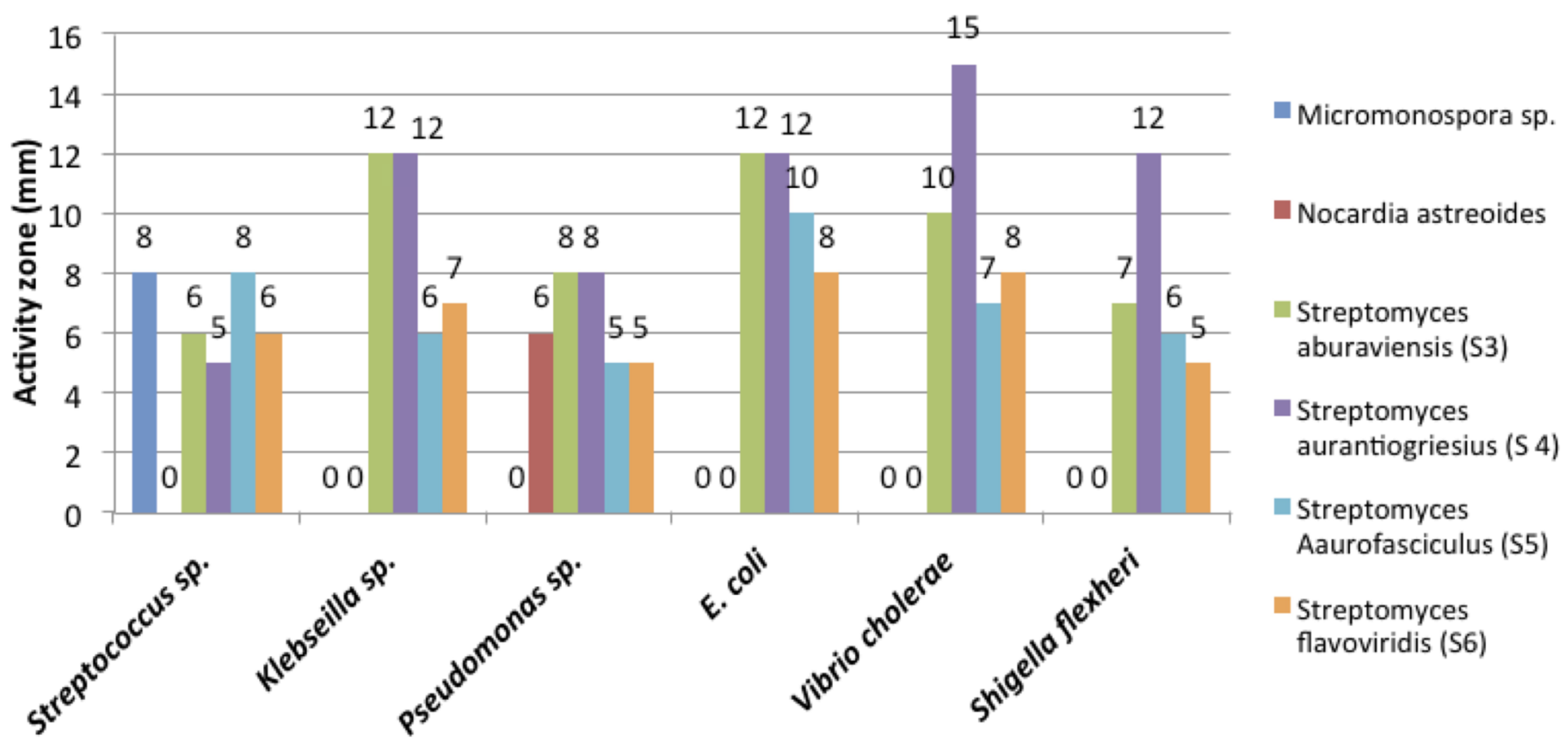

Figure 5: Antimicrobial activity of the isolates (zone of inhibition in $\mathrm{mm}$ ) 


\section{OPEN OACCESS}

But Ampicillin has shown better result for all pathogens, by producing clearing zone of $10 \mathrm{~mm}$. All the Streptomyces sp. showed good activity above $10 \mathrm{~mm}$ against E.coli sp. and Klebsiella sp., better than the antibiotic activity of Ampicillin.

A general conclusion could be drawn that marine environment yields a greater number of isolates per source that is comparable with that obtained from mangrove soils. On the other side, the number of isolates obtained from mangrove sediments is lower, particularly in the case of Actinobacteria. The present study shows that these isolated Actinobacterias strains, mostly Streptomycces spp. have shown antibacterial activity against the human pathogens and potential source of Actinobacteria from two-study area (Barmanallha and Carbyn's Cove) of south Andaman. It can be concluded that mangrove ecosystems of South Andaman have high potential Actinobacteria with bioactivity useful for identification of some novel compounds in future.

\section{ACKNOWLEDGMENTS}

The authors Dr. Jai Sunder and Ms. Sumitha Gopalakrishnan thankfully acknowledge the funding received under the scheme "Women Scientist program (WOS-A) Department of Science and Technology, Government of India (DST No: SR/WOS-A/ LS-205/2008 Dated 28/08/2009)" and the facilities provided by the Director, CIARI for conducting this work. The authors Dr. S. Venu and Mr. Sai Elangovan, S. are thankful to Pondicherry University for providing facilities for conducting this work.

\section{CONFLICT OF INTERESTS}

The authors have no conflict of interest exist related to this manuscript.

\section{AUTHORS' CONTRIBUTION}

Sumitha Gopalakrishnan and Sai Elangovan, Subramanian did the field sample collection and laboratory work. Dr. Jai Sunder and Dr. S. Venu guided these students and done part of the data analysis with bio-statistics and writing of the paper.

\section{REFERENCES}

-Alimuddin, Jaka W, Widya A, Mustofa (2011). Antifungal production of a strain of Actinomycetes spp isolated from the Rhizosphere of Cajuput Plant: Selection and detection of exhibiting activity against tested fungi. Alimuddin J. Biotechnol. 16 (1): 1-10.

-Badji B, Zitouni A, Mathieu F, Lebrihi A, Sabaou N (2006). Antimicrobial compounds produced by Actinomadura sp AC104 isolated from an Algerian Sahara soil. Can. J.
Advances in Animal and Veterinary Sciences Microbiol. 55 (4): 373-382. http://dx.doi.org/10.1139/w05132

-Basavaraj NK, Chandrashekhara S, Ali MS, Prakash SG, Fakirappa VM (2010). Isolation and Morphological Characterization of Antibiotic Producing Actinomycetes. Trop. J. Pharm. Res. 9 (3): 231-236. http://dx.doi. org/10.4314/tjpr.v9i3.56282

-Bentley SD, Chater KF, Cerdeño-Tárraga AM, Challis GL, Thomson NR, James KD, Harris DE, Quail MA, Kieser H, Harper D, Bateman A, Brown S, Chandra G, Chen CW, Collins M, Cronin A, Fraser A, Goble A, Hidalgo J, Hornsby T, Howarth S, Huang CH, Kieser T, Larke L, Murphy L, Oliver K, O'Neil S, Rabbinowitsch E, Rajandream MA, Rutherford K, Rutter S, Seeger K, Saunders D, Sharp S, Squares R, Squares S, Taylor K, Warren T, Wietzorrek A, Woodward J, Barrell BG, Parkhill J, Hopwood DA (2002). Complete genome sequence of the model Actinomycete Streptomyces coelicolor A3 (2). Nature. 417: 141-147. http://dx.doi.org/10.1038/417141a

- Damroy S, Krishnan P (2005). Mangrove stands of Andamans vis-à-vis tsunami. Curr. Sci. 89:1800-1804.

- Dastager SG, Damare S (2013). Marine actinobacteria showing phosphate solubilizing efficiency in Chorao Island, Goa, India. Curr. Microbiol. 66(5): 421-427. http://dx.doi. org/10.1007/s00284-012-0288-z

-El-Habib RS, Magda AE (2011). Isolation, identification and morphological characteristics of soil alkalophilic actinomycetes of Al-Qassim Region, Kingdom Saudi Arabia. J. Agri. Vet. Sc. Qassim University. 5 (2): 135-150.

-Flora DO, Adeyemi AI, George WP (2015). Himalomycin A and cycloheximide-producing marine actinomycete from Lagos Lagoon soil sediment. J. Coast. Life Med. 3: 361-365.

-FSI (2013). Status of forest report. Forest Survey of India (FSI), Dehra Dun.

-Gopalakrishnan S, Sunder J, Venu S (2014). Distribution of cultivable actinobacteria from the marine sediments along the Andaman Coast of Eastern Indian Ocean. Adv. Anim. Vet. Sci. 2 (12): 668-682. http://dx.doi.org/10.14737/ journal.aavs/2014/2.12.668.682

- Goodfellow M, Haynes J (1984). Actinomycetes in Marine Sediments. In Biological, Biochemical and Biomedical Aspects of Actinomycetes (eds. Oritz-Oritz, L., Bojali,C.F., and Yakoleff, V. ) Academic Press, New York, London. Pp. 453. http:// dx.doi.org/10.1016/B978-0-12-528620-6.50039-2

- Gunasekaran M, Thangavel S (2013). Isolation and screening of Actinomycetes from marine sediments for their potential to produce antimicrobials. Int. J. Life Sc. Bt. Pharm. Res. 2(3): 4-7.

-Hong K. Gao AH, Xie QY, Gao H, Zhuang L, Lin HP, Yu HP, Li J, Yao XS, Goodfellow M, Ruan JS. (2009). Actinomycetes for marine drug discovery isolated from mangrove soils and plants in China. Mar. Drugs. 7: 495-496.

-Jeffrey LSH, Sahilah AM, Son R, Tosiah S. (2007). Isolation and screening of actinomycetes from Malaysian soil for their enzymatic and antimicrobial activities. J. Trop. Agri. Food Sci. 35: 159-164.

- Labeda DP, Testa RT, Lechevalier MP, Lechevalier HA (1985). Glycomyces, a new genus of the Actinomycetales. Int. J. System. Bacteriol. 35: 417-421. http://dx.doi. org/10.1099/00207713-35-4-417

- Lechevalier HA, Lechevalier MP (1980). The chemotaxonomy of actinomycetes. In Actinomycete Taxonomy, Special Publication no.6, pp. 277-284. Edited by A. Dietz \& D. W. 
Thayer. Arlington, VA: Society of Industrial Microbiology.

- Nonomura H (1974). Key for classification and identification of 458 species of the Streptomycetes included in ISP. J. Ferment. Technol. 52: 78 - 92.

-Pandey A, Shukla A, Majumdar SK (2005). Utilization of carbon and nitrogen sources by Streptomyces kanamyceticus M27 for the production of an anti bacterial antibiotic. African J. Biotechnol. 4: 909-910.

-Pridham TG, Gottlieb D (1948). The utilization of carbon compounds by some actinomycetes as an aid for species determination. J. Bacteriol. 56(1): 107-114.

-Radhakrishnan M, Venugopal G, Ramasamy B, Kumar V (2015). Effect of critical medium components and culture conditions on anti-tubercular pigment production from novel Streptomyces sp D25 isolated from Thar desert, Rajasthan. J. Appl. Pharm. Sci. 5 (06): 015-019.

-Ragavan P Alok Saxena, Mohan PM, Ravichandran K, Jayaraj RSC, Saravanan S. (2015). Diversity, distribution and vegetative structure of mangroves of the Andaman and Nicobar Islands, India. J. Coast Conserv. 19 (3): 1-25.

-Sahoo D (2009). Pontential microbial diversity in mangrove ecosystems: A review. Indian J. Marine Sci. 38(2): 249-256.

-Sahu SM, Kathiresen (2005). Isolation and characterization of streptomycetes producing antibiotic from a mangrove environment. Asian J. Microb. Biotechnol. Environmental Sci. 7 (3): 457 - 464.

-Shirling EB, Gottlieb D (1966). Methods for characterization of Streptomyces species. Int.1 J. System. Bacteriol. 16: 313340. http://dx.doi.org/10.1099/00207713-16-3-313

- Sivakumar K, Sahu M, Kathiresan K (2005). Isolation and characterization of streptomycetes producing antibiotic from mangrove environment. Asian J. Microbial. Biotechnol. Environ. Sci. 7:457- 764.

-Talbot GH, Bradley J, Edwards JE, Gilbert D, Scheld M, Bartlett JG (2006). Bad bugs need drugs: an update on the development pipe-line from the antimicrobial availability task force of the Infectious Diseases Society of America. Clin. Infect. Dis. 42: 657-668. http://dx.doi.org/10.1086/499819

- Tamura K, Peterson D, Peterson N, Stecher G, Nei M, Kumar S (2011). MEGA5: Molecular evolutionary genetics analysis using maximum likelihood, evolutionary distance and maximum parsinomy methods. Mol. Biol. Evol. 28:27312739.

-Thenmozhi M, Kannabiran K (2012). Antimicrobial and antioxidant properties of marine actinomycete Streptomyces sp. VITSTK7. Oxidant. Antioxidant Med. Sci. 1: 51-57. http://dx.doi.org/10.5455/oams.270412.or.005

-Tomohiko T, Yuumi I, Moriyuki H, Misa O, Hideki Y, Masayuki H, Ken-ichiro S.(2011). Description of Actinomycetospora chibensis sp. nov., Actinomycetospora chlora sp. nov., Actinomycetospora cinnamomea sp. nov., Actinomycetospora corticicola sp. nov., Actinomycetospora lutea sp. nov., Actinomycetospora straminea sp. nov. and Actinomycetospora succinea sp. nov. Int. J. System. Evolution. Microbiol. 61: 1275-1280. http://dx.doi.org/10.1099/ijs.0.024166-0

-Udotong IR, John OUM, Udotong JIR (2008). Microbiological and physicochemical studies of wetland soils in Eket, Nigeria. Int. J. Biolog. Vet. Agri. Food Engin. 2 (8): 30-35.

-Vasavada SH, Thumar JT, Singh SP (2006). Secretion of a potent antibiotic by salt - tolerent and alkaliphilic actinomycete Streptomyces sannanensis strain RJT-1. Curr. Sci. 91: 13931397. 